\title{
1 Experimental techniques to assess coral physiology in situ: 2 current approaches and novel insights
}

\author{
3 Walter Dellisanti 1, 2, Jeffery T. H. Chung 1, Cher F. Y. Chow 1,4, Jiajun Wu 1, Mark L. Wells 5, 6, Leo L. Chan ${ }^{1,}$ \\ $2,3 *$ \\ ${ }^{1}$ State Key Laboratory of Marine Pollution, City University of Hong Kong, Hong Kong S.A.R., China; \\ ${ }^{2}$ Department of Biomedical Sciences, City University of Hong Kong, Hong Kong S.A.R., China; \\ ${ }^{3}$ Hong Kong Branch of Southern Marine Science and Engineering Guangdong Laboratory (Guangzhou), Hong Kong, \\ China; \\ ${ }^{4}$ Centre for Biological Diversity, Scottish Oceans Institute, School of Biology, University of St Andrews, Fife, UK; \\ ${ }^{5}$ School of Marine Sciences, University of Maine, Orono, USA; \\ ${ }^{6}$ State Key Laboratory of Satellite Ocean Environment Dynamics, Second Institute of Oceanography, Ministry of Natural \\ Resources, 36 Baochubei Road, Hangzhou, China 310012 \\ * Correspondence: leochan@cityu.edu.hk; Tel.: +852 34424125
}

Abstract: Coral reefs are declining worldwide due to global changes in the marine environment. The increasing frequency of massive bleaching events in the tropics is highlighting the need to better understand the stages of coral physiological responses to extreme conditions. Moreover, like many other coastal regions, coral reef ecosystems are facing additional localized anthropogenic issues such as nutrient loading, increased turbidity, and coastal development. Different strategies have been developed to measure the health status of a damaged reef, ranging from the resolution of individual polyps to an entire coral community, but techniques for measuring coral physiology in situ are not yet widely implemented. For instance, while there are many studies of the coral holobiont response in single or limited-number multiple stressor experiments, they provide only partial insights to metabolic performance under more complex temporally and spatially variable natural conditions. Here, we discuss the current status of coral reefs and their global and local stressors in the context of experimental techniques that measure core processes in coral metabolism (respiration, photosynthesis, and biocalcification) in situ, and their role in indicating the health status of colonies and communities. We highlight the need to improve the capability of in situ studies in order to better understand the resilience and stress response of corals under multiple global and local scale stressors.

Keywords: environmental monitoring; underwater respirometry; fluorometry; photobiology; coral metabolism

\section{Introduction}

Coral reef ecosystems are hotspots of biodiversity and productivity in the ocean [1] that exceed that of tropical rainforests [2]. They provide crucial ecosystem functions and services such as providing goods for subsistence and economic fisheries, coastline protection from storms, and centers of the growing field of ecotourism [3-5]. As a key habitat-forming taxa, corals are critical to both reef systems and the coastal human populations that rely on them, and it is imperative to accelerate advances to ensure the longevity and survival of corals and coral reefs.

Coral reefs have drastically declined worldwide in the last thirty years because of recruitment failures, reduced growth rates, and acute and chronic mortalities [6,7], with only a fraction expected to survive in the next three decades in the Indo-Pacific region [8,9]. One of the most significant and widespread anthropogenic causes of this degradation is the change in climate drivers associated with the rise in atmospheric carbon dioxide $\left(\mathrm{CO}_{2}\right)$ and other greenhouse gases [10,11]. Local stressors also go hand in hand with global stressors, such as coastline erosion or development, which threaten the resilience of corals through pollution and sedimentation. 
Increased energy consumption since the Industrial Revolution has led to the highest $\mathrm{CO}_{2}$ levels recorded in the atmosphere since human evolution (> $410 \mathrm{ppm}$ ) [12]. Of the multiple greenhouse gases (such as $\mathrm{N}_{2} \mathrm{O}, \mathrm{CH}_{4}$ or CFCs) affecting global biogeochemical cycles, biodiversity, and human health $[13,14], \mathrm{CO}_{2}$ has been the most relevant to marine ecology because of its dual role in marine heatwaves [15] and ocean acidification [16] (Figure 1). Overall average seawater temperatures in tropical regions have increased by almost $1^{\circ} \mathrm{C}$ over the past 100 years and are projected to continue increasing at $1^{\circ}$ to $2^{\circ} \mathrm{C}$ per century [17]. Increased seawater temperatures are a major contributor to coral bleaching and are considered as the limiting factor for coral survival $[7,18]$. Roughly half of the $\mathrm{CO}_{2}$ emitted into the atmosphere dissolves into the surface ocean, reacting with water to form several dissolved inorganic components of the carbonate system [19] and lowering seawater $\mathrm{pH}$ [20]. In comparison with pre-Industrial Revolution levels, seawater $\mathrm{pH}$ has decreased by approximately 0.1 [21], which equates to roughly $30 \%$ increase in acidity and may decrease further by 0.06 to 0.32 based on emission scenarios [16]. This process of ocean acidification is particularly disruptive to marine organisms like reef-building hard corals that create calcium carbonate skeletons, increasing the energy requirements for growth and survival $[20,22,23]$. Thus, corals and coral reefs may be significantly more vulnerable than previously thought when ocean acidification and warming combine [24,25].

Although climate drivers are widely recognized as dominating factors in coral loss and reef ecosystem shifts [18], localized stressors also are impacting coral health, where a survival-resilience pattern is observable in urban subtropical reefs subjected to several anthropogenic stressors [26]. Here, there are indications that stress-tolerant hard coral species have been selected to foster more resistant though less diverse reefs [27]. Impacts from eutrophication, increased turbidity, and lowered dissolved oxygen significantly affect coral metabolism, changing energy pathways and reef ecology (Figure 1). A coral as a holobiont, including all its functional, genomic and epigenetic associated symbionts, is capable of ecological plasticity in order to survive environmental changes, but not all coral species showed the same response patterns under anthropogenic threats.

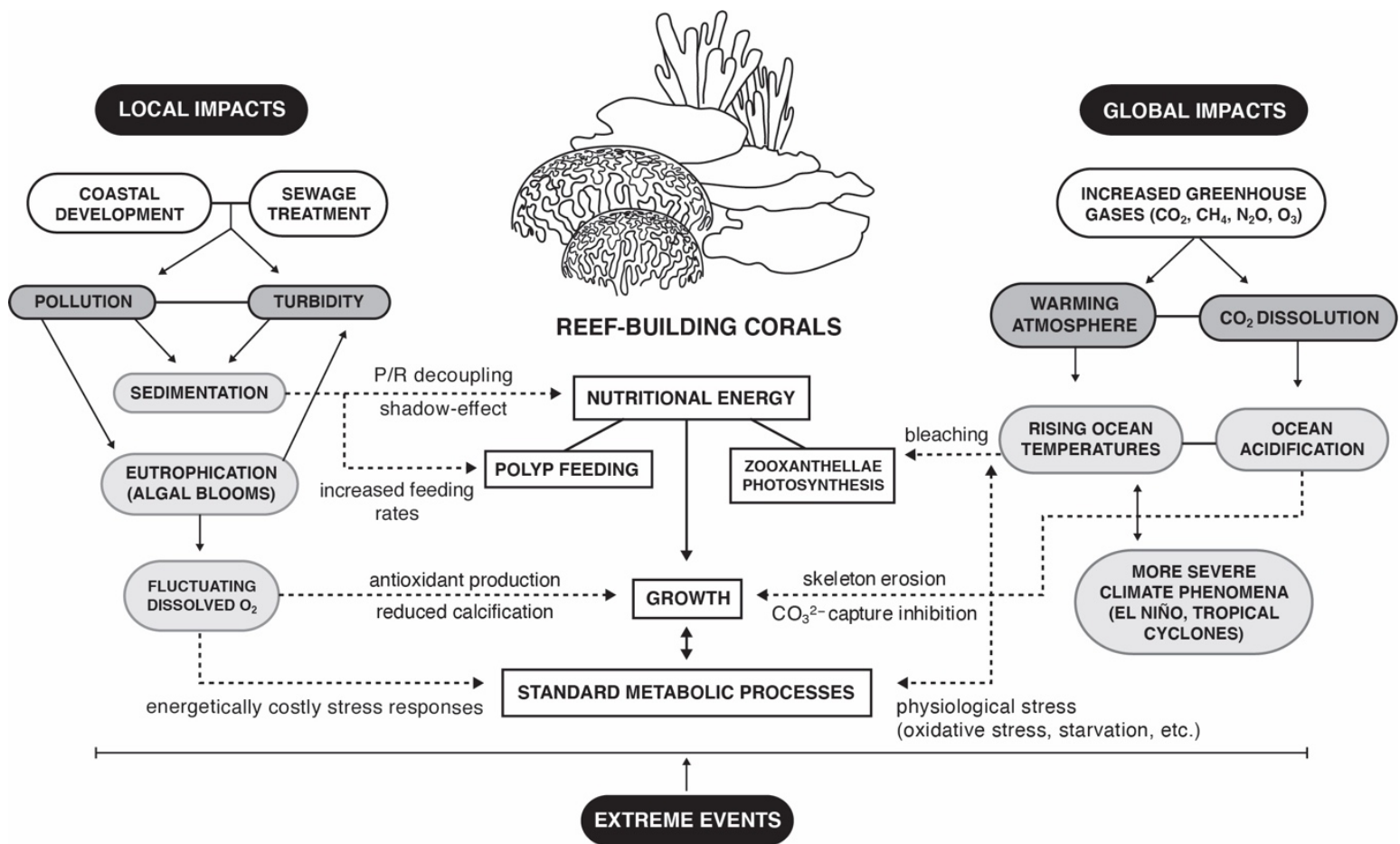

Figure 1. Local and global impacts affecting the nutritional energy of reef-building corals. Full lines indicate direct interactions, dotted lines indicate indirect interactions.

Turbid water conditions commonly occur within inshore shallow coastal waters [28], owing to the collective interactions of river runoff and the natural re-suspension of sediments (e.g. tides or storms) as well as 
anthropogenic activities (e.g. ship wakes, coastline modification, storm and other sewage discharge). The adaptive responses required to survive these conditions are both stressful and energetically costly [29], utilizing energy that otherwise would be put towards growth and reproduction. One of the consequences of increased turbidity is the reduction of the in situ irradiance supporting photosynthesis, and settling sediments can further smother coral polyps [30]. The resulting decreases in photosynthetic efficiencies and increases in respiration reduce the daily productivity of corals (measured as the ratio of photosynthesis to respiration, $\mathrm{P} / \mathrm{R}$ ) as well as the relative nutritional energy requirements, such as reduced lipids content and change in lipids class composition [31]. Lower P/R also can increase coral susceptibility to infection and bleaching [32], generating community- and ecosystem-level impacts. Corals adjacent to urban developments are frequently exposed to acute sedimentation but do not suffer tissue mortality because they appear to have acclimated to low light conditions [33] with increased feeding rates to offset energy deficits from photosynthesis [34]. However, the increased frequency and severity of acute sedimentation in coastal waters contributes additional stress to corals that potentially are functioning near the limits of their physiological tolerances $[31,35,36]$.

High oxygen concentrations from over-primary production (e.g. the first stage of an algal bloom) can bring oxygen intoxication, resulting in coral damage and photorespiration [37], due to a shift of the use of energy into the production of antioxidants rather than calcification [38]. On the other hand, natural fluctuations of dissolved oxygen concentrations in coastal seawater and shallow coral reef can stimulate physiological rates and promote adaptation to the adjusted environment. However, low oxygen concentrations may have a significant effect on the survival behavior of corals. Although hypoxic events and dead zones in the tropical coral reef are poorly investigated and rarely reported, episodic or seasonal hypoxia has been recently associated with bleaching and mortality in deeper corals rather than shallow colonies [39].

Eutrophication has degraded many coral reefs in coastal regions, and high-nutrient waters exacerbate the effect of global warming on coral survival [40]. The nutrient gradient affects the nutritional status of corals, in particular when the calcification rate is reduced but heterotrophy enhanced under high nutrient loading [41]. Indeed, traces of nitrate pollution can be found in both hard and soft corals through the analysis of radioisotopes $\delta^{15} \mathrm{~N}$ in the tissue [42,43] and $\delta^{13} \mathrm{C}$ as an estimate of particulate organic matter ingestion [44,45]. At the community level, a shift from net community calcification to dissolution can occur under high nutrient conditions [46], due to combination of direct (physiological status) and indirect (biogeochemical status) responses of corals [46,47]. Eutrophic conditions can increase the productivity of reef waters by increasing food availability (e.g., particulate matter) [30], although macroalgae, turf and bioeroders can inhibit competitively the coral recruitment [47]. However, several factors influencing the susceptibility to eutrophication have to be included, such as hydrodynamic, connectivity and location [48].

Gaining knowledge of the stress responses of corals and their effects on reef ecology, along with the pathways to best minimize these impacts, depends on two related tasks: understanding coral health from polypendosymbiont symbiosis to the community level, and achieving early detection of the onset of the stress responses. The first provides the foundation for studying and developing potential mitigation and managements strategies, and the second is crucial for implementing these strategies soon enough to help minimize impacts.

While most early studies of environmental change on coral health focused on the effects of single drivers (e.g., temperature, ocean acidification, turbidity, etc.), their interactive effects require addressing multiple stressor effects on physiological processes at the holobiont level if we are to comprehensively understand their impacts on coral communities. Some of these effects are major (e.g., temperature and light), but there undoubtably are other interactions subtle enough to challenge recognition but significant enough that they can affect the resistance and recovery response of coral communities, factors critical for reef management in proactive preventative planning. But our current understanding of coral stress responses is largely based on experimental manipulation studies in laboratory systems that are poor replicants of their natural habitats. In situ studies, by either SCUBA or automated sensors, could provide a better understanding of local and global impacts, but few studies have undertaken the logistical complexities of studying fine-scale physiological processes of corals in situ recently [49-51]. The primary objective of this review is to summarize the current strategies used to measure the metabolism of corals to highlight the benefits of non-destructive methodologies. 
126 A list of recommendations is provided that would expand the efficacy of underwater studies for improving

127 local knowledge and better understanding of how corals respond to stressors.

\section{2. Overview of the coral metabolism}

\section{2. 1. Metabolic responses at coral polyp level}

The concept of the coral as a "holobiont" was introduced in the 2000s [52,53] which comprises the coral polyps and the associated symbiotic organisms, including photosynthetic endosymbionts, bacteria, viruses, fungi and protists. These have a fundamental role in nutrient and energy acquisition processes of coral polyps [54], genome evolution in the coral host and microbial partners, maintaining holobiont homeostasis, and the overall health of the holobiont [55]. The functional diversity of these microbes contributes to the stress response and acclimation to abnormal conditions, e.g. high seawater temperature and bleaching events [56,57].

The family Symbiodiniaceae includes several genera of dinoflagellates which reside in the tissue of corals and other marine organisms [58]. The coral-Symbiodiniaceae association is an obligate symbiosis for the coral, where the photosynthetic dinoflagellates provide the coral oxygen and energy in the form of glucose for aerobic respiration $[59,60]$. While most of the oxygen arising from photosynthesis is immediately utilized in coral respiration [61-63], the excess oxygen is released to the surrounding seawater throughout the day [64-67], supporting the oxygen availability on the reef. Therefore, at night, corals must acquire oxygen from the surrounding environment to fuel the respiration process [64]. As a consequence, the energy acquisition follows a circadian pattern where endosymbiont-guided photosynthesis is dominant during the day while polypguided respiration is dominant at night.

This continuous loop is stable in normal conditions, but the symbiotic dynamics within the coral holobiont is changing rapidly in the Anthropocene [68]. Temperature-induced stress damages a key protein (D1) in the photosystem II within the dinoflagellate (PSII; [69]), inactivating the Rubisco center [70], affecting the production of ATP [71], and leading to the overproduction of reactive oxygen species, inducing damaging conditions for both the endosymbiont and coral host. The increased frequency and severity of temperature anomalies will lead to negative consequences for coral survival [20,72]. Under warming and eutrophic conditions, this symbiosis may shift from a mutualistic to parasitic strategy for nutritional resources allocation [73], and the positive feedback loop for nutrient acquisition can be disrupted when conditions are not favorable to support the benefits of the $\mathrm{O}_{2} / \mathrm{CO}_{2}$ fluxes [74,75].

The coral symbioses also can be influenced by other types of stress related to environmental changes. The impact of high seawater $p \mathrm{CO}_{2} /$ low $\mathrm{pH}$ on corals is highly variable, where it can stimulate growth and photosynthetic efficiency in certain Symbiodiniaceae species [76], which suggests that the presence of carbonconcentrating mechanisms in the endosymbiont can lead to strain in the symbiotic relationship [77]. Eutrophic conditions of seawater, such as elevated concentration of nitrates $\left(\mathrm{NO}_{3}^{-}\right)$or phosphate $\left(\mathrm{PO}_{4}^{3-}\right)$, can stimulate both photosynthesis and respiration rates in corals, but not concomitant increase of net calcification [46] bringing to unbalanced efficiency of symbiosis in the coral health. However, ammonia $\left(\mathrm{NH}_{4}{ }^{+}\right)$enrichment can support the resistance to thermal stress, but not $\mathrm{NO}_{3}{ }^{-}$which can bring to increased levels of reactive species and oxidative damage [78].

Bleaching, where the endosymbionts may decrease their chlorophyll content or be ejected from the coral host, signals severe physiological consequences arising from oxidative stress and starvation, leading to reduced respiration rates and energy acquisition [79]. Although bleaching can be a reversible condition, it often leads to coral tissue death if sustained too long. However, endosymbionts have developed adaptive mechanisms to limit thermal stress by increasing electron flow in photosystem I as photoprotection [80], thereby limiting the extent of bleaching. Moreover, corals polyps may partially compensate for the lost photosynthetically-derived energy during bleaching by enhanced feeding if sufficient prey are available [32].

\section{$170 \quad$ 2. 2. Responses of the coral community}


When magnified across coral tissues, the polyp-level metabolic responses can affect reefs at community level. Growth of coral colony, or net community calcification, is measured in terms of the deposition of its calcium carbonate $\left(\mathrm{CaCO}_{3}\right)$ foundation, which is determined largely by coral energy reserves and the need to maintain optimal chemical conditions at the tissue/calcium carbonate interface. Hard corals build their skeleton of $\mathrm{CaCO}_{3}$ through the uptake of calcium and carbonate ions from seawater. The reaction occurs in the calicoblastic cells lining the surface where primary crystal secretion occurs [22] and is facilitated at $\mathrm{pH}$ levels above that of seawater. However, ocean acidification reduces the seawater $\mathrm{pH}$ and the aragonite saturation state $(\Omega a)$ [23], which can have a strong effect on net community calcification (NCC), along with the balance of organic matter production and respiration, or net community production (NCP) [81]. Moreover, the projected decreases in $\mathrm{pH}$ in the future ocean eventually will affect the stability of existing reef ecosystems, because the $\mathrm{CaCO}_{3}$ formed by corals (aragonite) is more susceptible to dissolution than that formed by other bio-calcifying organisms [82]. These effects overlay natural seasonal variations in the carbonate chemistry in reef systems, and the question remains of what extent does globally and locally derived ocean acidification have on the seasonal balance of NCP and NCC [83]. However, these estimates remain imprecise, owing to the lack of information about seawater residence time and volume, which would modulate reef chemistry [84]. The relationship between corals and their symbiotic dinoflagellates is exacerbated under the combined effects global drivers of stress, leading to lower energy reserves for growth $[6,20,85,86]$, and local impacts of eutrophic conditions of seawater surrounding the coral reefs, causing reduced calcification, oxidative stress, and eventually leading to bleaching events [46,78].

Even with these impacts though, it is possible for coral communities to recover after destructive events. For example, the coral reef in Kane'ohe Bay showed positive NCC and NCP about one year after the last drastic bleaching event in 2015 [87], indicating the capacity of local rapid post-bleaching recovery. However, these estimates considered only the abiotic factors, such as carbonate chemistry and oceanographic patterns, without considering potential effects from the benthic community which would contribute to the depletion or repletion of alkalinity in the coral reef [88].

Defining the health of corals and coral communities is complex because of array of elements that contribute the status of reef ecosystems. The coral micro-environment comprises ecologically-dependent niches that contribute to the general homeostasis and plasticity - i.e., resilience - to the coral holobiont. But understanding the responses to variable multistressor conditions in their in situ environments is not adequately informed by only laboratory-based manipulation studies, so the adaptive resilience of coral species and their influence the reef systems remains only partially understood. It is difficult then to chart ways forward for pragmatic and effective steps towards protection and restoration. Determining how to overcome these limitations will depend on applying new, in situ observational techniques that can bridge from single organisms to ecosystems and then to the global scale.

\section{Methods}

We conducted a literature review based on case studies of in situ observations of coral metabolism from published peer-reviewed scientific literature. We included cases involved in original research on direct (e.g., using SCUBA divers, benthic chambers, optical sensors) underwater measurements of metabolic rates on both coral individuals and coral communities. We excluded sample collections (e.g., coral fragmentation), laboratory experiments, and indirect measurements of metabolic fluxes (e.g., ex situ from sample incubations).

We used the advanced search on Google Scholar to identify studies with the keywords "coral in situ metabolism" and "underwater", excluding the keyword "collection", in articles published between 1991 and 2020. The search yield $(n=2090)$ was scrutinized, and the literature was manually reviewed to fulfil our selection criteria described above. A final list of 54 studies was included for the analysis in this review.

The literature screening was categorized in eight separate categories based on the methodology used (Table 1), including: 1) SCUBA FRR fluorometry; 2) SCUBA PAM fluorometry; 3) Clark-type $\mathrm{O}_{2}$ sensors; 4) boundary layer; 5) SCUBA imaging; 6) benthic chambers; 7) submersible chambers; and 8) automated sensors. The database was further classified based on the system type (open, semi-closed, enclosed); measured parameters 
$\left(\mathrm{O}_{2}, \mathrm{Fv} / \mathrm{Fm}, \mathrm{ETR}, \mathrm{CA}\right)$; sampling frequency (minutes, hours, days); sampling scale (symbionts, polyp, colony, community); and aim of the study (monitoring, experiment).

Through the analysis of the literature screened, we ranked the database by publication year (Table 2) and identified the most commonly used techniques for studying in situ coral metabolism. Finally, we analyzed the objectives of the studies included in this review (Fig. 2) in order to give an overview on the topics mostly studied between 1991 and 2020.

\section{Results}

\subsection{Methodologies and objectives for coral in situ metabolism}

Several tools and instruments have been developed for measuring coral physiology in both field and laboratory studies. The ability to non-invasively measure metabolic and physiological processes makes these methods well-suited for studying both healthy and stressed organisms. The use of diver-portable technologies, designed to non-destructively estimate energy production and expenditure, such as respirometers and fluorometers, is discussed in this review. However, there is little consensus about the extent to which apparently healthy corals are adapting to the changing conditions [89]. Measurements of metabolic proxies such as variations in dissolved oxygen and $\mathrm{pH}$ have been used at both individual coral and coral community scales to infer the metabolic state of benthic ecosystems [90], and link these indicators to the wider contribution the ecosystem's nutrient cycle and biogeochemistry.

Previous convention for laboratory-based manipulation studies for coral metabolism have involved destructive sampling of individual or fragments of a coral colony. Although this framework provides crucial knowledge on separate isolated physiological mechanisms and pathways, these controlled conditions do not comprehensively reflect the stochasticity and cyclical fluctuations in environmental conditions on a reef and the effects of multiple chronic or acute stressors. In the last decades, experimental techniques to detect the metabolic status of corals directly in situ have been developed, using specific tools engineered for automated analysis on coral surface and reef communities. Among these, microsensors and benthic chambers for respirometry and fluorometry techniques became the most popular for coral surface studies even with different applications (Table 1).

Table 1. Experimental techniques available for in situ monitoring of coral physiological processes.

\begin{tabular}{|c|c|c|c|c|c|}
\hline Method & System & Parameters & $\begin{array}{l}\text { Sampling } \\
\text { frequency }\end{array}$ & $\begin{array}{l}\text { Sampling } \\
\text { scale }\end{array}$ & Aim \\
\hline $\begin{array}{l}\text { SCUBA FRR } \\
\text { fluorometry }\end{array}$ & Open & ETR, Fv/Fm & Minutes & Symbionts & Monitoring \\
\hline $\begin{array}{l}\text { SCUBA PAM } \\
\text { fluorometry }\end{array}$ & Semi-closed & ETR, Fv/Fm & Minutes & Symbionts & Monitoring \\
\hline $\begin{array}{l}\text { Clark-Type } \mathrm{O}_{2} \\
\text { microsensor }\end{array}$ & Open & $\mathrm{O}_{2}$ & Hours & $\begin{array}{l}\text { Symbionts, } \\
\text { Polyp }\end{array}$ & $\begin{array}{l}\text { Experiment, } \\
\text { Monitoring }\end{array}$ \\
\hline $\begin{array}{l}\text { Diffusive Boundary } \\
\text { Layer }\end{array}$ & Semi-closed & $\mathrm{O}_{2}, \mathrm{CA}$ & Minutes & $\begin{array}{l}\text { Symbionts, } \\
\text { Polyp }\end{array}$ & Monitoring \\
\hline SCUBA imaging & Open & $\mathrm{O}_{2}$ & Hours & $\begin{array}{l}\text { Symbionts, } \\
\text { Polyp, Colony }\end{array}$ & Monitoring \\
\hline Benthic chamber & Enclosed & $\mathrm{O}_{2}, \mathrm{CA}$ & Days & Colony & $\begin{array}{l}\text { Experiment, } \\
\text { Monitoring }\end{array}$ \\
\hline $\begin{array}{l}\text { Submersible } \\
\text { chamber }\end{array}$ & Enclosed & $\mathrm{O}_{2}, \mathrm{CA}$ & Hours & $\begin{array}{l}\text { Colony, } \\
\text { Community }\end{array}$ & $\begin{array}{l}\text { Experiment, } \\
\text { Monitoring }\end{array}$ \\
\hline Automated sensors & Open & $\mathrm{O}_{2}, \mathrm{CA}$ & Hours & Community & Monitoring \\
\hline
\end{tabular}


SCUBA FRR: SCUBA-based fast respiration rate fluorometer; SCUBA PAM fluorometry: SCUBA-based pulse amplitude modulation; $\mathrm{O}_{2}$ : Dissolved oxygen; CA: Calcification; ETR: Electron transport rate; Fv / Fm: maximum quantum yield of photosystem II.

The focus of instrumentation development for in situ studies of coral metabolism has shifted over the last three decades from the host-symbiosis relationship using fluorometric techniques to measure the photosynthetic efficiency of endosymbionts to a more comprehensive investigation of individuals and communities (Table 2). Indeed, through the use of benthic chambers it is possible to run experimental manipulations of carbon fluxes or nutrients and monitor long-term ecosystem responses via automated sensors. With this shift, the biogeochemical processes involved in corals and coral reefs have received advanced understanding of ecosystems functioning with the possibility to predict benthic conditions using modelling of future scenarios [51].

Table 2. Time ranking of published peer-reviewed studies on coral in situ metabolism according to this study.

\begin{tabular}{llll}
\hline Year & Methodology & Objective & Sampling scale \\
\hline $1991-2005$ & $\begin{array}{l}\text { fluorometry, benthic and } \\
\text { submersible chamber }\end{array}$ & productivity, diel change & Polyp, colony \\
\hline $2006-2010$ & $\begin{array}{l}\text { fluorometry, benthic } \\
\text { chamber, automated } \\
\text { sensors }\end{array}$ & $\begin{array}{l}\text { diel change, productivity, } \\
\text { physiology under stress }\end{array}$ & Colony, community \\
\hline $2011-2015$ & $\begin{array}{l}\text { Benthic and submersible } \\
\text { chamber, diffusive } \\
\text { boundary layer }\end{array}$ & $\begin{array}{l}\text { physiology under stress, } \\
\text { productivity }\end{array}$ & $\begin{array}{l}\text { Colony, polyp, } \\
\text { community }\end{array}$ \\
\hline $2016-2020$ & $\begin{array}{l}\text { benthic/submersible } \\
\text { chamber, automated } \\
\text { sensors }\end{array}$ & $\begin{array}{l}\text { seasonal change, } \\
\text { productivity, physiology } \\
\text { under stress }\end{array}$ & Colony, community \\
\hline
\end{tabular}

Among the objectives of coral physiology studies, investigating the diel or seasonal changes in primary productivity comprised 59\% of the published works, highlighting that quantification of natural variations in energetic fluxes are a central concern for the assessment of coral conditions (Fig. 2). Moreover, coral productivity was the only objective of study being covered by all methodologies at different sampling scales, from polyp to community. Conversely, 25\% of studies addressed coral physiology under stress, including bleaching responses, environmental changes and bathymetric change conditions (transplantation). The assessment of recovery of health status was investigated by $9 \%$ of the studies. The remaining papers centered on issues of zonation (4\%) and photo-inhibition (3\%). 


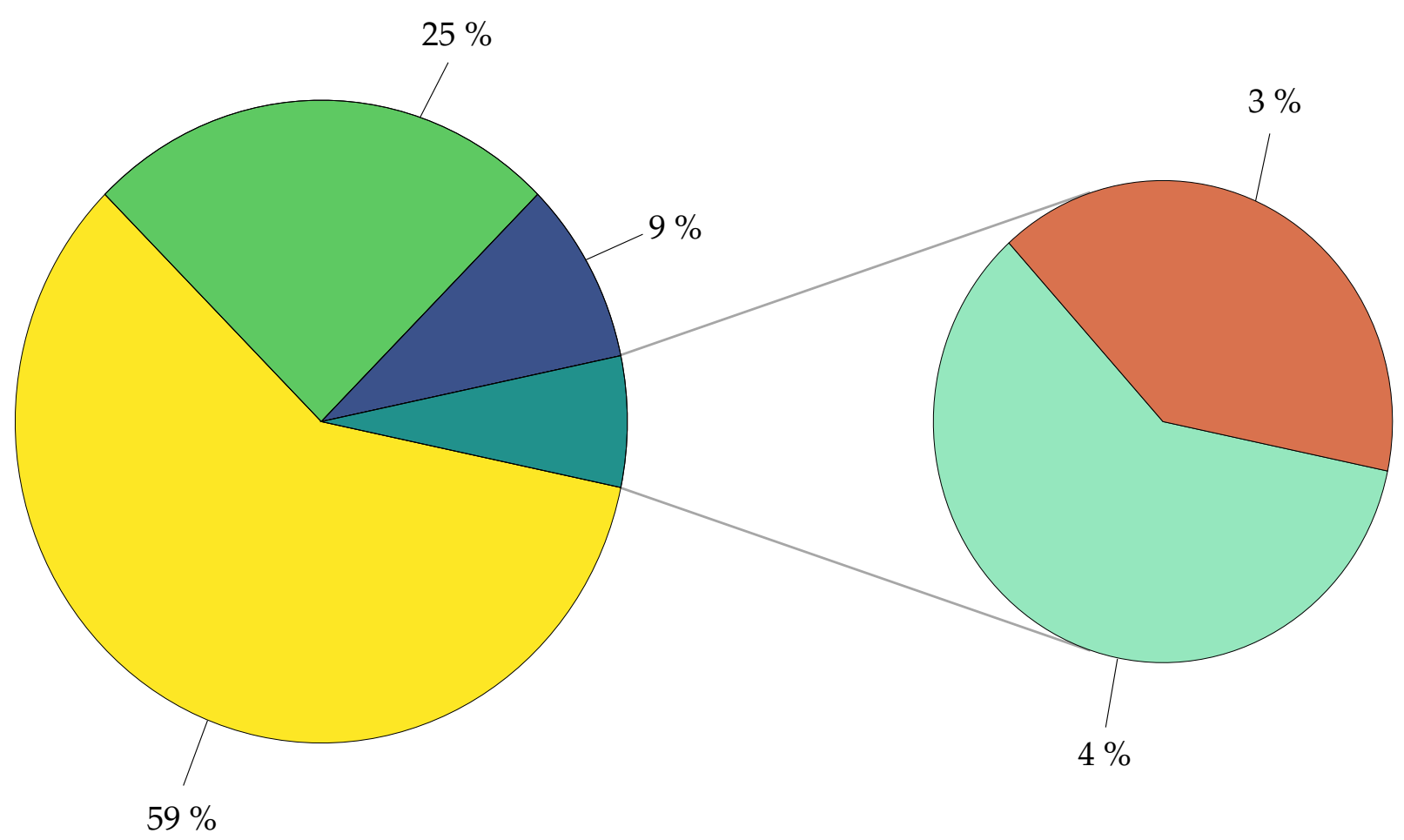

$\square$ Primary productivity $\square$ Physiology under stress $\square$ Assessing recovery

Zonation $\quad \square$ Photo-inhibition

272 Figure 2. Study objectives of in situ methodologies for the measurement of coral physiology

\section{2. Underwater fluorometry}

The photochemical performance of coral endosymbionts is a key aspect influencing the health of scleractinian corals, so measures of holobiont photophysiology provide insight to coral metabolic status. Fluorometry can provide insight in two broad ways: a measure of the abundance, character, and distribution of light-harvesting pigments and fluorescent proteins in corals (i.e., the potential energy source), and the photophysiological status of the endosymbiont i.e., how well these pigments are being used to generate energy for the coral.

A fundamental measure of coral status is quantification of the light harvesting pigments of the endosymbionts over time, whereby decreasing trends can provide early warning of the onset of bleaching events. The underwater fluorescence imaging has been adapted to conduct large-scale in situ assessments of coral reefs, through the detection of green fluorescent proteins in corals [91,92]. Because the concentration of these pigments and fluorescent proteins are directly involved in photoprotection and photo-acclimation, quantifying the concentrations present in a coral population or community can provide crucial information on bleaching susceptibility or resistance [93-95]. In addition, this imaging technique can also make early signs of disease and coral juveniles easier to detect for accurate enumeration [96], providing a facet of coral reef health [92].

Early in situ studies on coral physiology estimated the rates of photosynthesis and respiration within recirculating chambers by measuring changes in oxygen concentrations [97]. While still a highly useful approach (see below), the introduction of variable fluorescence techniques has greatly increased the ability to assess the 
293

294

295

296

297

298

299

300

301

302

303

304

305

306

307

308

309

310

311

312

313

314

315

316

317

318

319

320

321

322

323

324

325

326

327

328

329

330

331

332

333

334

335

336

337

338

339

340

photophysiology of the endosymbionts, and thus provide a sensitive indicator of their metabolic status. With variable fluorescence, very rapid pulses of light are used to probe the photosystems and inform on a number of photosynthetic parameters including the quantum yield of photosystem II (PSII), which is used as a metric for photosynthetic rates [98] and is a key indicator of the physiological status of the endosymbiont. Changes in photosynthetic efficiency provides an early signal of stress, some of which is a natural response to changes in irradiance but become more prolonged and severe when conditions of imminent bleaching occur.

The estimation of the potential quantum yield of PSII as a metric for photosynthetic rates was first applied to underwater organisms by Beer et al. [99]. Pulse amplitude modulated (PAM) fluorometer uses light pulses of relatively long duration (300 - $1200 \mathrm{~ms}, 3000-10000 \mu \mathrm{mol}$ photons $\mathrm{m}^{-2} \mathrm{~s}^{-1}$ ) to modify the fluorescence yields, generating multiple turnover for the reduction of PSII, allowing non-invasive chlorophyll fluorescence analysis, quantum yield and electron transport rate of coral endosymbionts. The introduction of an underwater version of this instrument (Diving-PAM, Walz) facilitated the direct observation of changes in coral health in situ conditions [100]. The introduction of in situ PAM fluorometry enabled the construction of photosynthesisirradiance models for corals based on varying sun exposures in reefs $[99,100]$. For example, observations of decreased quantum yield during the day reflected photoinhibition through loss of photosynthetic capacity; a response seen in shallow but not deeper water corals [101]. Similar reduced photosynthetic efficiency has been observed in corals exposed to seasonal turbid conditions [102]. The use of Diving-PAM continuous monitoring during bleaching events also showed that combined thermal and light stress generated greater reductions in photosynthetic efficiency, and was a sensitive indicator of metabolic stress in impacted areas [103]. Even so, variable responses in the coral community to this stress suggested coral species-specific physiological responses [104-107]. Further development on PAM technology is the high-resolution imaging fluorometry used for analysis of heterogeneity within colonies, from coenosarc tissue to polyp tentacles, but so far this methodology is not available for underwater studies [108].

A second approach for measuring variable fluorescence, the FRR fluorometer uses a different approach to saturate the photochemistry during measurement, whereby shorter $\left(150-400 \mu \mathrm{s},>20000 \mu \mathrm{mol}\right.$ photons $\left.\mathrm{m}^{-2} \mathrm{~s}^{-1}\right)$ but more intense light is used to generate a single turnover and reduction of the primary electron acceptor $[109,110]$. The methodology is more sensitive than PAM, which can be beneficial when endosymbiont abundance (or chlorophyll concentrations) is very low in corals. The SCUBA-based FRR fluorometry was developed by Gorbunov et al. [111] for measuring chlorophyll fluorescence from PSII reaction centers in corals, sea grasses, macroalgae and algal turfs. FRR fluorometry has been also used to monitor coral physiology during bleaching events, and their later recovery [112,113]. Although nutrient availability (as nitrogen or iron) and sunlight irradiance were already recognized as the main factors directly affecting photosynthesis in the aquatic ecosystem [114,115], the use of FRR fluorometry enabled more direct measurements to the effects of nutrient limitation on photosynthetic efficiency of corals. Indeed, the FRR fluorometry predicted which corals might be more susceptible to bleaching under stress conditions even when no signs of stress are visible, but photosynthetic quantum yield was reduced [116].

The use of submersible chambers combined respirometry and fluorometric techniques (see below), and have been used to study the evolution of diurnal hysteresis in coral photosynthesis in situ $[117,118]$. However, some discrepancy in the findings were found, and were interpreted as being derived from the different scales of measurements, where FRR and PAM fluorometry measured the fluorescence signal at polyp-symbiont scale [111] while oxygen measurements integrate the whole colony [119]. Moreover, differences are in the system design, where FRR and PAM are fluorometry probes in open systems, while benthic chambers encloses the studied organisms in a confined system. This caveat aside, fluorescence instruments (Diving-PAM, FRR and imaging systems) have become popular for studying photosynthetic performance of coral symbionts and monitoring the diel change of coral productivity, favored by accessible costs and portability of these instruments for underwater studies.

\subsection{Benthic chambers, diffusive flux methods, and flow analyses}


Early in situ studies on coral biology used the strategy of encapsulating single or multiple individuals within a closed benthic systems [120]. These chambers enabled the non-destructive measurement of coral physiological rates through changes in water chemistry to better understand community level responses to perturbation [120,121]. For example, incubation chambers have been used to study in situ coral calcification and photosynthesis rates, where the effect of ocean acidification was shown to lower the calcification rates [122]. Large incubation systems have enabled measurements of benthic community metabolism as well as conducting in situ experiments, providing better insight to ecological responses in reefs than can more focused studies of host-symbiont relationships.

The common metrics to assess the health of corals are the levels of photosynthesis by the endosymbionts, respiration of the holobiont, and ideally the rates of biocalcification (or growth). Benthic chambers are wellsuited to measure these essential parameters in situ [123-126]. For example, differences in coral metabolism were measured between shallow (reef flat) and deeper area (reef slope) at Ishigaki Island, Japan, with negative net calcification rates being attributed to nighttime decreases in $\mathrm{pH}$ due to benthic respiration [127]. In another study, Sawall et al. [41] used benthic chamber to study the coral nutritional status at elevated anthropogenic nutrient loading. The design of a transparent 3-L urine bag as the "Flexi-Chamber" made it easily usable at lowcost by any underwater scientists, where short incubations detected changes in biological processes with no visual signs of coral stress or endosymbionts concentration [126]. A similar design was used as benthic chambers to show that abiotic conditions including light intensity were drivers of spatial-temporal patterns of reef metabolism [128], although some limitations on the use of these incubation chambers emerged when applied on large boulder colonies. For instance, the amount of light available for photosynthesis, and relative energetic budget, can have different role based on colony shape (micro niches) and surround environment (backscattering light) [129]. However, non-invasive diver-portable in situ incubation chambers ( $70 \mathrm{~L}, 0.2 \mathrm{~m}^{2}$ area) have been developed for reproducible measurements of biogeochemical processes in both simple and structurally complex reef communities, allowing the in situ study of various benthic habitats, such as corals, sediments and seagrass meadows [51]. The introduction of benthic and submersible chambers has made it possible to link individual metabolic host-symbionts focuses to community-wide responses, improving the generality and robustness of previous metabolic and physiology studies.

An ambitious program to use benthic chambers as flow respiratory systems to study the in situ response of a coral community was begun in the early 2000's. The "Submersible Habitat for Analyzing Reef Quality" was designed to maintain and measure a turbulent flow of water over benthic substrates for extended periods while measuring temperature, oxygen, salinity, $\mathrm{pH}$ and irradiance (photosynthetically active radiation) and to monitor the daily variations in photosynthesis, respiration, and calcification [130]. This system enabled some of the first studies of the direct influence of high $\mathrm{CO}_{2}$ levels on coral communities in short term experiments [130], although the strength of this approach is the ability to study of the ecology and biogeochemistry of coral communities over multiple days. A similar system was used as automated closed-chamber for application over a variety of substrate types [131].

These flow systems have launched new investigations into the effects of environmental stressors on reef metabolism, ecology, and biogeochemistry. The combination of in situ flow chambers and fluorometry techniques in experimental studies, like that conducted at the underwater laboratory NOAA Aquarius [132], demonstrated the effect of increased water flow and temperature on coral physiology. These applications were used to demonstrate asymmetric patterns of photosynthetic yield across coral colonies [133], where the upper side has a reduced quantum yield [134]. Other experimental studies have been conducted using flow chambers to study coral physiology under chemical enrichment in a benthic chamber experiment [135] adding new findings on coral responses to high $p \mathrm{CO}_{2}$ and the combined effect of chemical inputs and global warming. Another system, such as the collapsible benthic isolation tents (cBITs) [136], was used to assess the combined effects of benthic communities, from corals to algae and microbes, over diurnal cycles, highlighting the importance of contribution to reef metabolism and DOC by different compartments.

A new diver-portable tool has been developed for community in situ metabolism (CISME) that enables short-term (minutes) experimentation with flow and chemical manipulations, as well as in situ measurements 
390 of coral metabolic health and rates of calcification [137]. Although its use has been limited to date, it offers the

391

392

393

394

395

396

397

398

399

400

401

402

403

404

405

406

407

408

409

410

411

412

413

414

415

416

417

418

419

420

421

422

423

424

425

426

427

428

429

430

431

432

433

434

435

436

437

438 ability for the assessment of individual corals across and among reef environments with high accuracy and resolution. Similarly, small benthic chambers enclosing 70 L [51] were used to study complex benthic structures and to measure coral reef community budgets of primary production over coral-dominated or alge-dominated reef communities [138] adding new findings on the biogeochemical cycles of coral reef ecosystems.

Benthic chambers offer the chance to assess the variability of responses within and among reefs, but by design these systems alter water flow dynamics around the study corals and restrict water exchange sufficiently to enable changes to accumulate in water chemistry (i.e., the measurement parameters at a minimum). It is unclear at what stage these changes in water flow and bulk chemical conditions may begin influencing coral responses. Unenclosed, diffusive boundary layer (DBL) approaches were developed to avoid these potential issues, whereby sensors placed well above the coral interface make unobstructed measurements of vertical gradients in velocity, temperature, and chemical constituents on the open reef to calculate the flux of momentum, heat, and $\mathrm{O}_{2}$ in the boundary layer [139].

\section{4. Micro- and automated sensors}

The use of microsensors at coral tissue levels [129,140-143] and automated sensors at community level [144-146] reveals new insights into coral metabolism by showing the fluctuations in chemical conditions under different natural regime of dissolved oxygen, marine $\mathrm{pH}$ and light intensity. For example, the oxygen saturation at coral-water interface fluctuates from supersaturated during daytime due to production by endosymbionts, to hypoxic at night due to respiration by both polyps and symbionts [60,63,147]. However, despite these broad chemical changes, oxygen microsensors used in the microenvironment of coral-turf and coral-corallinae algae showed that low oxygen concentrations were not generally found at the interface of Porites spp., turf algae, and crustose coralline algae [141]. More microenvironment studies are needed to better understand the metabolic regulation between corals and the surrounding environment [129]. Technological development of microsensors in a modified diver-operated system [148] allowed the quantification of irradiance at the coral surface and the measurement of the efficiency of photosynthetic system at polyp and coenosarc microscale [149], confirming the ability of corals to adapt to environmental changes, such as temperature or irradiance [150]. On a broader scale, micro- and automated sensors increasingly have been used in both closed (benthic chamber) and open (reef-scale) approaches to studying coral and reef ecologies.

\section{5. Reef scale experiments}

The study of corals in open or unconfined natural systems using DBL techniques was made possible by the advent of sensors for measuring both water flow and relevant aspects of water chemistry. A common approach is to use eddy correlation techniques [151] where non-invasive acoustic doppler velocimeters measuring water flow are coupled with $\mathrm{O}_{2}$ sensors to provide three-dimensional fields of oxygen distribution over benthic environments [152]. This application can examine in situ dynamics of $\mathrm{O}_{2}$ production and consumption (i.e., respiration) in different habitats, including highly productive reef crests relative to reef slopes [152] as well as cold-water (deep) coral reefs [153,154]. These ecosystem-scale measurements show how high oxygen fluxes are possible, even in nutrient replete environments such as reef slopes and deep waters. The advantage of such techniques has been discussed by Takeshita et al. [155] who introduced a new autonomous system (the benthic ecosystem and acidification measurement system) for simultaneous measurement of NCP and NCC from a coral reef through the autonomous use of $\mathrm{O}_{2}$ and $\mathrm{pH}$ sensing technology. Moreover, direct observation of the effect of increased $p \mathrm{CO}_{2} /$ lowered $\mathrm{pH}$ environments on corals showed temporal and spatial metabolic response of reef diversity and water chemistry to high $\mathrm{CO}_{2} /$ low $\Omega \mathrm{a}$, at temporal and spatial patterns [144].

Comparison between the enclosed and open system approaches showed good general agreement with respect to discrete measurements of oxygen from the gradient flux (GF) method at the DBL and a multiparametric probe in a benthic chamber [130], although other findings indicate that GF method can offer more accurate measurements of these fluxes [139]. The low physical disruption with DBL methods means both less direct impacts on corals and more spatially integrative observation and interpretation of coral reef responses 
439 to changes in the natural environment at colony or community levels. Their smaller infrastructure requirements also make them an attractive strategy for investigations. Even so, these approaches can be complementary. For example, DBL studies show that water flow can be a factor affecting the light-limited photosynthesis in coral colonies [65], and more spatially focused studies have used benthic chambers to show that increased water flow leads to increased calcification rates, carbonate deposition, protein concentration and endosymbionts density [156].

Experiments at reef scale represent a key step forward in the in situ studies of coral responses in the natural environment [49,157-159], but they also have provided the opportunity to quantify reef-scale responses to environmental perturbations. For example, manipulations to lower $\Omega$ a by $\sim 20 \%$ led to a $34 \%$ decrease in NCC consistent with the effect of lower $\mathrm{pH}$ on biocalcification [160], although this finding may have been influenced by a high abundance of crustose corallinae algae living in the reef community [159]. Another free ocean $\mathrm{CO}_{2}$ enrichment (FOCE) system was used to incubate coral reef communities at ambient $p \mathrm{CO}_{2}(393 \mu \mathrm{atm})$ and high $p \mathrm{CO}_{2}(949 \mu \mathrm{atm})$, and a decrease in daily NCC by $49 \%$ under high $p \mathrm{CO}_{2}$ was observed over a 21 days experiment, corresponding to $26 \%$ reduction in NCC per unit of $\Omega$ a [157]. These results were in line with previous studies on ecosystem-level responses of coral reef communities to ocean acidification level projected in the next century. Indeed, a modification of such an experimental system, the coral-proto free ocean carbon enrichment system, allowed the short-term in situ study of the induced ocean acidification on coral reef organisms and diel changes of the seawater carbonate system [158]. Srednick et al. [49] introduced another novel FOCE for spatial and temporal studies on shallow reefs, with the aim of studying a coral reef community in situ under controlled conditions of current and projected levels of $p \mathrm{CO}_{2}$. Such a system allowed a direct estimation of the hysteresis of seawater carbonate chemistry along a reef transect, using high accuracy and precision measurements of seawater $\mathrm{pH}, p \mathrm{CO}_{2}$ and the biological responses of the reef community over high temporal resolution [49]. Other high frequency sampling of coral reef carbonate dynamics and metabolic rates have used automated systems for measurements of alkalinity, $\mathrm{pH}$ and $\mathrm{COO}_{2}$ at high frequency sampling [50,145]. Through automated measurements with the slack water and flow respirometry approaches, it is now possible to characterize the net calcification and productivity of a reef system (either reef flats or crests), as well as reveal long-term changes driven by global changes (ocean acidification and global warming) or hysteresis under local changes $[145,161]$. However, dissimilarities in the methods used in community metabolism studies [162], create potential uncertainties when applied to coral reefs, in terms of community calcification and seawater carbonate conditions. Limitations of metabolic studies at community level are related to lack of suitable controls, spatial heterogeneities and thus replicability among sites, as well as confounding factors in open systems, such as the introduction of organisms and differing oceanographic settings in the surrounding reef environments.

\section{1}

\section{Discussion}

Underwater methodologies from 54 studies on coral metabolism and physiology conducted since 1991 have been collated (Table 1). The current knowledge of combined effects of local and global stressors comes from a wide breadth of manipulation studies on coral responses under predicted future scenarios but limited in representing complex abiotic factors in ecosystems. The interaction among environmental variables, such as temporal changes in inorganic carbon chemistry, physical parameters, or nutrient loads, is an important factor affecting the biogeochemistry of coral health [157], and can play a key role in population dynamics. Though invaluable as a study tool, manipulation studies are limited in the ability to mimic important spatiotemporal patterns and interactions. On the other hand, comprehensive long-term in situ metabolic measurements still are lacking but nevertheless necessary to understand the energetics and trophodynamic of reef ecosystems.

Laboratory-based studies have provided a strong foundation for understanding coral metabolism and the responses to stress, and they will continue to serve as a primary means of research under controlled conditions. However, the expanding role of in situ-based studies of coral systems is essential for extrapolating and modulating these laboratory-based findings to the temporal and spatial complexity of natural reef and environmental conditions. The advantages of in situ experimental techniques described relate to the ability for 
486 measuring metabolic and biogeochemical properties of different benthic habitats having both simple and complex structures. The replicability of experimental studies, for example using same methodology or sensors, allows the simultaneous monitoring of coral health in different locations with the ability to compare the ecosystem functions, e.g., standardization of the methods. However, there are limitations to in situ methodologies. In the case of benthic chambers, there are restrictions to which substrate surfaces are suitable for study, and they are not well suited, even with enhanced flow capabilities, for longer-term monitoring of coral health. Yet, benthic chambers are restricted to limited benthic area of the reef, with no accounting of the energy processes from the entire ecosystem (macroalgae, fish, etc.) In the case of DBL approaches, limitations include the needed maintenance and fragility of microsensors, which can limit deployments to shorter duration, or under more quiescent weather conditions. Co-deployment of multiple instrumentation approaches will be needed to ensure both accuracy and logistic practicality in monitoring fluxes of $\mathrm{O}_{2}$ and $\mathrm{pH}$ in coral reefs. Even with these accounted for, most studies on coral metabolic rates rely on observation of changes in DIC and alkalinity in a specific (small) area to calculate the carbon fluxes for productivity and calcification estimates [163]; the precise movement of seawater flow and aspects of reef heterogeneity cannot be fully taken into account, leading to potentially biased findings that may not adequately reflect natural conditions. In reality then, a combination of in situ techniques likely will be most useful, such as the application of flow respirometry approaches to estimate carbon fluxes over a small spatial scales and different substrate type within a reef, coupled with DBL methods that provide an integrative assessment of the temporal variability in coral productivity and growth [145].

Author Contributions: Conceptualization, W.D. and J.C.; methodology, W.D. and J.C..; formal analysis, W.D. and J.C..; investigation, W.D..; resources, W.D. and J.C.; data curation, W.D.; writing-original draft preparation, W.D.; writingreview and editing, W.D., J.C., C.C., J.W., M.W., L.C; visualization, W.D. and C.C.; supervision, L.C..; project administration, J.W. and L.C.; funding acquisition, J.W. and L.C. All authors have read and agreed to the published version of the manuscript.

Funding: This study was supported by the Hong Kong Branch of Southern Marine Science and Engineering Guangdong Laboratory (Guangzhou) (SMSEGL20SC02); the Collaborative Research Fund (C7013-19G) of the Hong Kong Research Grants Council; the National Natural Science Foundation of China (41641047); the Internal Research Project of State Key Laboratory of Satellite Ocean Environment Dynamics, Second Institute of Oceanography, State Oceanic Administration (No. SOEDZZ1702) and the SKLMP Seed Collaborative Research Fund (SCRF/0027).

516 Acknowledgments: The authors thank Prof. John Hodgkiss for the proof-reading.

517 Conflicts of Interest: the authors declare no conflict of interest.

\section{References}

520 1. Roberts, C. M.; McClean, C. J.; Veron, J. E. N.; et al. Marine biodiversity hotspots and conservation priorities for

2. Ray, C. G. Ecological Diversity in Coastal Zones and Oceans. In Wilson, E. O., Peter, F. M., eds. Biodiversity; National

3. Cesar, H.; Burke, L.; Pet-Soede, L. The Economics of Worldwide Coral Reef Degradation. International Coral Reef Action Academies Press (US), 1988. https://www.ncbi.nlm.nih.gov/books/NBK219271/.

$526 \quad 4 . \quad$ Knowlton, N.; Brainard, R. E.; Fisher, R.; Moews, M.; Plaisance, L.; Caley, M. J. Coral Reef Biodiversity. In Life in the World's Oceans; Wiley-Blackwell, 2010; 65-78. doi:10.1002/9781444325508.ch4.

5. Van Zanten, B. T.; Van Beukering, P. J. H.; Wagtendonk, A. J. Coastal protection by coral reefs: A framework for spatial assessment and economic valuation. Ocean Coast. Manag. 2014, 96:94-103. 
doi:10.1016/j.ocecoaman.2014.05.001.

531

532

533

534

535

536

537

538

539

540

541

542

543

544

545

546

547

548

549

550

551

552

553

554

555

556

557

558

559

560

561

562

563

564

565

566

567

568

6. Hughes, T. P.; Bellwood, D. R.; Baird, A. H.; Brodie, J.; Bruno, J. F.; Pandolfi, J. M. Shifting base-lines, declining coral cover, and the erosion of reef resilience: Comment on Sweatman et al. (2011). Coral Reefs. 2011, 30(3):653-660. doi:10.1007/s00338-011-0787-6.

7. Hughes, T. P.; Kerry, J. T.; Baird, A. H.; et al. Global warming impairs stock-recruitment dynamics of corals. Nature. 2019, 568(7752):387-390. doi:10.1038/s41586-019-1081-y.

8. Descombes, P.; Wisz, M. S.; Leprieur, F.; et al. Forecasted coral reef decline in marine biodiversity hotspots under climate change. Glob. Chang. Biol. 2015, 21(7):2479-2487. doi:10.1111/gcb.12868.

9. Bruno, J. F.; Selig, E. R. Regional decline of coral cover in the Indo-Pacific: Timing, extent, and subregional comparisons. PLoS One. 2007, 2(8). doi:10.1371/journal.pone.0000711.

10. Goulletquer, P.; Gros, P.; Boeuf, G.; et al. Status and Trends. In Biodiversity in the Marine Environment; Springer Netherlands, 2014;21-84. doi:10.1007/978-94-017-8566-2_3.

11. Hannah, L. Impacts of Anthropogenic $\mathrm{CO}_{2}$ and Climate Change on the Biology of Terrestrial and Marine Systems. In Kendall, R. J., Lacher, T. E., Cobb, G. C., Cox, S. B., Lacher, T. E., eds. Wildlife Toxicology: Emerging Contaminant and Biodiversity Issues; CRC Press, 2016;165-190. doi:10.1201/9781439817957-11.

12. Dlugokencky, E.; Tans, P. Global Monitoring Laboratory - Carbon Cycle Greenhouse Gases. US Department of Commerce, NOAA, Global Monitoring Laboratory. Published 2020. Accessed July 6, 2020. www.esrl.noaa.gov/gmd/ccgg/trends.

13. Bustamante, M. M. C.; Nardoto, G. B.; Pinto, A. S.; Resende, J. C. F.; Takahashi, F. S. C.; Vieira, L. C. G. Potential impacts of climate change on biogeochemical functioning of Cerrado ecosystems. Brazilian J. Biol. 2012, 72(3 SUPPL.):655-671. doi:10.1590/S1519-69842012000400005.

14. Galloway, J. N.; Dentener, F. J.; Capone, D. G.; et al. Nitrogen cycles: Past, present, and future. Biogeochemistry. 2004, 70(2):153-226. doi:10.1007/s10533-004-0370-0.

15. Gruber, N. Warming up, turning sour, losing breath: ocean biogeochemistry under global change. Philos. Trans. R. Soc. A Math. Phys. Eng. Sci. 2011, 369(1943):1980-1996. doi:10.1098/rsta.2011.0003.

16. Ciais, P.; Sabine, C.; Bala, G.; Peters, W. Carbon and other biogeochemical cycles. In Climate Change 2013 the Physical Science Basis: Working Group I Contribution to the Fifth Assessment Report of the Intergovernmental Panel on Climate Change; Vol 9781107057. Cambridge University Press, 2013;465-570. doi:10.1017/CBO9781107415324.015.

17. Kuffner, I. B.; Lidz, B. H.; Hudson, J. H.; Anderson, J. S. A Century of Ocean Warming on Florida Keys Coral Reefs: Historic In Situ Observations. Estuaries and Coasts. 2015, 38(3):1085-1096. doi:10.1007/s12237-014-9875-5.

18. Hughes, T. P.; Kerry, J. T.; Álvarez-Noriega, M.; et al. Global warming and recurrent mass bleaching of corals. Nature. 2017, 543(7645):373-377. doi:10.1038/nature21707.

19. Zeebe, R. E.; Wolf-Gladrow, D. CO2 in Seawater: Equilibrium, Kinetics, Isotopes. Elsevier Oceanography Series 65. Published October 15, 2001. https://www.elsevier.com/books/co2-in-seawater-equilibrium-kineticsisotopes/zeebe/978-0-444-50946-8.

20. Anthony, K. R. N.; Kline, D. I.; Diaz-Pulido, G.; Dove, S.; Hoegh-Guldberg, O. Ocean acidification causes bleaching and productivity loss in coral reef builders. Proc. Natl. Acad. Sci. U. S. A. 2008, 105(45):17442-17446. doi:10.1073/pnas.0804478105.

21. Caldeira, K.; Wickett, M. E. Anthropogenic carbon and ocean pH. Nature. 2003, 425(6956):365. doi:10.1038/425365a. 
569 22. Cohen, A.; Holcomb, M. Why Corals Care About Ocean Acidification: Uncovering the Mechanism. Oceanography. 2009, 22(4):118-127. doi:10.5670/oceanog.2009.102.

23. Eyre, B. D.; Andersson, A. J.; Cyronak, T. Benthic coral reef calcium carbonate dissolution in an acidifying ocean. Nat. Clim. Chang. 2014, 4(11):969-976. doi:10.1038/nclimate2380.

24. Hoegh-Guldberg, O.; Mumby, P. J.; Hooten, A. J.; et al. Coral reefs under rapid climate change and ocean acidification. Science. 2007, 318(5857):1737-1742. doi:10.1126/science.1152509.

26. Heery, E. C.; Hoeksema, B. W.; Browne, N. K.; et al. Urban coral reefs: Degradation and resilience of hard coral assemblages in coastal cities of East and Southeast Asia. Mar. Pollut. Bull. 2018, 135(July):654-681. doi:10.1016/j.marpolbul.2018.07.041.

Darling, E. S.; Alvarez-Filip, L.; Oliver, T. A.; Mcclanahan, T. R.; Côté, I. M. Evaluating life-history strategies of reef corals from species traits. Ecol. Lett. 2012, 15(12):1378-1386. doi:10.1111/j.1461-0248.2012.01861.x. three near-shore turbid water corals. Mar. Ecol. Prog. Ser. 2014, 502:129-143. doi:10.3354/meps10714.

29. Brown, B.; Bythell, J. Perspectives on mucus secretion in reef corals. Mar. Ecol. Prog. Ser. 2005, 296:291-309. doi:10.3354/meps296291.

30. Fabricius, K. E. Effects of terrestrial runoff on the ecology of corals and coral reefs: Review and synthesis. Mar. Pollut.

31. Jones, R.; Giofre, N.; Luter, H. M.; Neoh, T. L.; Fisher, R.; Duckworth, A. Responses of corals to chronic turbidity. temperature, light, and sediment regime. Limnol. Oceanogr. 2007, 52(2):716-726. doi:10.4319/lo.2007.52.2.0716.

33. Dubinsky, Z.; Falkowski, P. G.; Porter, J. W.; Muscatine, L. Absorption and utilization of radiant energy by lightand shade-adapted colonies of the hermatypic coral Stylophora pistillata. Proc. R. Soc. London. Ser. B. Biol. Sci. 1984, 222(1227):203-214. doi:10.1098/rspb.1984.0059. turbidity. J. Exp. Mar. Bio. Ecol. 2000, 252(2):221-253. doi:10.1016/S0022-0981(00)00237-9.

35. Bessell-Browne, P.; Negri, A. P.; Fisher, R.; Clode, P. L.; Duckworth, A.; Jones, R. Impacts of turbidity on corals: The relative importance of light limitation and suspended sediments. Mar. Pollut. Bull. 2017, 117(1-2):161-170. doi:10.1016/j.marpolbul.2017.01.050.

37. Mass, T.; Genin, A.; Shavit, U.; Grinstein, M.; Tchernov, D. Flow enhances photosynthesis in marine benthic autotrophs by increasing the efflux of oxygen from the organism to the water. Proc. Natl. Acad. Sci. U. S. A. 2010, 107(6):2527-2531. doi:10.1073/pnas.0912348107.

38. Wijgerde, T.; Silva, C. I. F.; Scherders, V.; Van Bleijswijk, J.; Osinga, R. Coral calcification under daily oxygen saturation and $\mathrm{pH}$ dynamics reveals the important role of oxygen. Biol. Open. 2014, 3(6):489-493. doi:10.1242/bio.20147922. 
608 39. Altieri, A. H.; Harrison, S. B.; Seemann, J.; Collin, R.; Diaz, R. J.; Knowlton, N. Tropical dead zones and mass mortalities on coral reefs. Proc. Natl. Acad. Sci. 2017, 114(14):3660-3665. doi:10.1073/pnas.1621517114.

610

40. DeCarlo, T. M.; Gajdzik, L.; Ellis, J.; et al. Nutrient-supplying ocean currents modulate coral bleaching susceptibility. Sci. Adv. 2020, 6(34):eabc5493. doi:10.1126/sciadv.abc5493.

612

613

614 coral Stylophora subseriata along a eutrophication gradient in Spermonde Archipelago (Indonesia). Coral Reefs. 2011, 30(3):841-853. doi:10.1007/s00338-011-0764-0.

616

43. Baker, D. M.; Kim, K.; Andras, J. P.; Sparks, J. P. Light-mediated 15N fractionation in Caribbean gorgonian

Duprey, N. N.; Wang, X. T.; Thompson, P. D.; et al. Life and death of a sewage treatment plant recorded in a coral skeleton $\triangle 15 \mathrm{~N}$ record. Mar. Pollut. Bull. 2017, 120(1-2):109-116. doi:10.1016/j.marpolbul.2017.04.023.

619

44. Baker, D. M.; Jordán-Dahlgren, E.; Maldonado, M. A.; Harvell, C. D. Sea fan corals provide a stable isotope baseline for assessing sewage pollution in the Mexican Caribbean. Limnol. Oceanogr. 2010, 55(5):2139-2149. doi:10.4319/lo.2010.55.5.2139.

Conti-Jerpe, I. E.; Thompson, P. D.; Wong, C. W. M.; et al. Trophic strategy and bleaching resistance in reef-building corals. Sci. Adv. 2020, 6(15):5443-5453. doi:10.1126/sciadv.aaz5443. coastal management and reef survival. Curr. Opin. Environ. Sustain. 2014, 7:82-93. doi:10.1016/j.cosust.2013.11.029.

48. Fabricius, K. E. Factors determining the resilience of coral reefs to eutrophication: A review and conceptual model.

Srednick, G.; Bergman, J. L.; Doo, S. S.; et al. Shallow coral reef free ocean carbon enrichment: Novel in situ flumes to manipulate $\mathrm{pCO}_{2}$ on shallow tropical coral reef communities. Limnol. Oceanogr. Methods. 2020, 18(3):116-128. doi:10.1002/lom3.10349.

Cyronak, T.; Takeshita, Y.; Courtney, T. A.; et al. Diel temperature and $\mathrm{pH}$ variability scale with depth across diverse coral reef habitats. Limnol. Oceanogr. Lett. 2020, 5(2):193-203. doi:10.1002/lol2.10129.

51. Roth, F.; Wild, C.; Carvalho, S.; et al. An in situ approach for measuring biogeochemical fluxes in structurally disease and evolution. Nat. Rev. Microbiol. 2007, 5(5):355-362. doi:10.1038/nrmicro1635.

54. Peixoto, R. S.; Rosado, P. M.; Leite, D. C. de A.; Rosado, A. S.; Bourne, D. G. Beneficial microorganisms for corals doi:10.3389/fmicb.2017.00341. 
646 56. Hume, B. C. C.; Voolstra, C. R.; Arif, C.; et al. Ancestral genetic diversity associated with the rapid spread of stresstolerant coral symbionts in response to holocene climate change. Proc. Natl. Acad. Sci. U. S. A. 2016, 113(16):44164421. doi:10.1073/pnas.1601910113.

57. Jones, A. .; Berkelmans, R.; van Oppen, M. J. .; Mieog, J. .; Sinclair, W. A community change in the algal endosymbionts of a scleractinian coral following a natural bleaching event: field evidence of acclimatization. Proc. R. Soc. B Biol. Sci. 2008, 275(1641):1359-1365. doi:10.1098/rspb.2008.0069.

58. LaJeunesse, T. C.; Parkinson, J. E.; Gabrielson, P. W.; et al. Systematic Revision of Symbiodiniaceae Highlights the Antiquity and Diversity of Coral Endosymbionts. Curr. Biol. 2018, 28(16):2570-2580.e6. doi:10.1016/j.cub.2018.07.008.

59. Muscatine, L. The role of symbiotic algae in carbon and energy flux in reef corals . In Dubinsky, Z., ed. Ecosystems of the World; Vol 25. Elsevier, 1998;75-87. https://www.scienceopen.com/document?vid=c3e2e66a-41da-4a83-8fb9$88316 \mathrm{db} 544 \mathrm{bf}$.

60. Gardella, D. J.; Edmunds, P. J. The oxygen microenvironment adjacent to the tissue of the scleractinian Dichocoenia stokesii and its effects on symbiont metabolism. Mar. Biol. 1999, 135(2):289-295. doi:10.1007/s002270050626.

61. Al-Horani, F. A.; Al-Moghrabi, S. M.; De Beer, D. The mechanism of calcification and its relation to photosynthesis and respiration in the scleractinian coral Galaxea fascicularis. Mar. Biol. 2003, 142(3):419-426. doi:10.1007/s00227-0020981-8.

62. Al-Horani, F. A.; Al-Moghrabi, S. M.; De Beer, D. Microsensor study of photosynthesis and calcification in the scleractinian coral, Galaxea fascicularis: Active internal carbon cycle. J. Exp. Mar. Bio. Ecol. 2003, 288(1):1-15. doi:10.1016/S0022-0981(02)00578-6.

63. Kuhl, M.; Cohen, Y.; Dalsgaard, T.; Jorgensen, B. B.; Revsbech, N. P. Microenvironment and photosynthesis of zooxanthellae in scleractinian corals studied with microsensors for 02, pH and light. Mar. Ecol. Prog. Ser. 1995, 117:159-172.

64. Al-Horani, F. A.; Tambutté, É.; Allemand, D. Dark calcification and the daily rhythm of calcification in the scleractinian coral, Galaxea fascicularis. Coral Reefs. 2007, 26(3):531-538. doi:10.1007/s00338-007-0250-x.

65. Finelli, C. M.; Helmuth, B. S. T.; Pentcheff, N. D.; Wethey, D. S. Water flow influences oxygen transport and photosynthetic efficiency in corals. In Coral Reefs; Vol 25. Springer, 2006;47-57. doi:10.1007/s00338-005-0055-8.

66. Mass, T.; Genin, A.; Shavit, U.; Grinstein, M.; Tchernov, D. Flow enhances photosynthesis in marine benthic autotrophs by increasing the efflux of oxygen from the organism to the water. Proc. Natl. Acad. Sci. U. S. A. 2010, 107(6):2527-2531. doi:10.1073/pnas.0912348107.

67. Yonge, S. C. M.; Nicholls, A. G.; Yonge, M. J. The relationship between respiration in corals and the production of oxygen by their zooxanthellae. Sci. Reports / Gt. Barrier Reef Exped. 1928-29. 1932, 1:213-251. Accessed July 7, 2020. https://www.biodiversitylibrary.org/part/183504.

68. Hughes, T. P.; Barnes, M. L.; Bellwood, D. R.; et al. Coral reefs in the Anthropocene. Nature. 2017, 546(7656):82-90. doi:10.1038/nature22901.

69. Hill, R.; Brown, C. M.; DeZeeuw, K.; Campbell, D. A.; Ralph, P. J. Increased rate of D1 repair in coral symbionts during bleaching is insufficient to counter accelerated photo-inactivation. Limnol. Oceanogr. 2011, 56(1):139-146. doi:10.4319/lo.2011.56.1.0139.

70. Lilley, R. M.; Ralph, P. J.; Larkum, A. W. D. The determination of activity of the enzyme Rubisco in cell extracts of the dinoflagellate alga Symbiodinium sp. by manganese chemiluminescence and its response to short-term thermal stress of the alga. Plant, Cell Environ. 2010, 33(6):995-1004. doi:10.1111/j.1365-3040.2010.02121.x. 
686 71. Franklin, D.; Hoegh-Guldberg, O.; Jones, R.; Berges, J. Cell death and degeneration in the symbiotic dinoflagellates

687 of the coral Stylophora pistillata during bleaching. Mar. Ecol. Prog. Ser. 2004, 272:117-130. doi:10.3354/meps272117.

Randall, C. J.; Szmant, A. M. Elevated temperature affects development, survivorship, and settlement of the elkhorn

73. Lesser, M. P.; Stat, M.; Gates, R. D. The endosymbiotic dinoflagellates (Symbiodinium sp.) of corals are parasites and

74. Douglas, A. E. Conflict, cheats and the persistence of symbioses. New Phytol. 2008, 177(4):849-858. doi:10.1111/j.1469-

75. Baker, D. M.; Freeman, C. J.; Wong, J. C. Y. Y.; Fogel, M. L.; Knowlton, N. Climate change promotes parasitism in a coral symbiosis. ISME J. 2018, 12(3):921-930. doi:10.1038/s41396-018-0046-8.

76. Brading, P.; Warner, M. E.; Davey, P.; Smith, D. J.; Achterberg, E. P.; Suggett, D. J. Differential effects of ocean acidification on growth and photosynthesis among phylotypes of Symbiodinium (Dinophyceae). Limnol. Oceanogr. 2011, 56(3):927-938. doi:10.4319/lo.2011.56.3.0927.

698 calcification in coral reef communities exposed to elevated $\mathrm{pCO}_{2}$; Biogeosciences. 2017, 14(14):3549-3560. doi:10.5194/bg-14-3549-2017.

702

703

78. Fernandes de Barros Marangoni, L.; Ferrier-Pagès, C.; Rottier, C.; Bianchini, A.; Grover, R. Unravelling the different causes of nitrate and ammonium effects on coral bleaching. Sci. Rep. 2020, 10(1):11975. doi:10.1038/s41598-020-689160.

79. Williams, D. E.; Miller, M. W.; Bright, A. J.; Pausch, R. E.; Valdivia, A. Thermal stress exposure, bleaching response, and mortality in the threatened coral Acropora palmata. Mar. Pollut. Bull. 2017, 124(1):189-197. doi:10.1016/j.marpolbul.2017.07.001.

80. Hoogenboom, M. O.; Campbell, D. A.; Beraud, E.; DeZeeuw, K.; Ferrier-Pagès, C. Effects of light, food availability and temperature stress on the function of photosystem II and photosystem I of coral symbionts. PLoS One. 2012, 7(1). doi:10.1371/journal.pone.0030167.

83. Cyronak, T.; Andersson, A. J.; Langdon, C.; et al. Taking the metabolic pulse of the world's coral reefs. Voolstra, C.

81. Albright, R.; Benthuysen, J.; Cantin, N.; Caldeira, K.; Anthony, K. Coral reef metabolism and carbon chemistry dynamics of a coral reef flat. Geophys. Res. Lett. 2015, 42(10):3980-3988. doi:10.1002/2015GL063488.

84. Courtney, T. A.; Lebrato, M.; Bates, N. R.; et al. Environmental controls on modern scleractinian coral and reef-scale

85. Hoegh-Guldberg, O. Coral reefs in the anthropocene: Persistence or the end of the line? Geol. Soc. Spec. Publ. 2014, calcification. Sci. Adv. 2017, 3(11):e1701356. doi:10.1126/sciadv.1701356. 
in Kāne'ohe Bay, Hawai'i. Limnol. Oceanogr. Lett. 2018, 3(1):1-9. doi:10.1002/lol2.10056.

726

727

728

729

730

731

732

733

734

735

736

737

738

739

740

741

742

743

744

745

746

747

748

749

750

751

752

753

754

755

756

757

758

759

760

761

762

763

88. Page, H. N.; Courtney, T. A.; Collins, A.; De Carlo, E. H.; Andersson, A. J. Net community metabolism and seawater carbonate chemistry scale non-intuitively with coral cover. Front. Mar. Sci. 2017, 4(MAY):161. doi:10.3389/fmars.2017.00161.

89. Baker, A. C.; Glynn, P. W.; Riegl, B. Climate change and coral reef bleaching: An ecological assessment of long-term impacts, recovery trends and future outlook. Estuar. Coast. Shelf Sci. 2008, 80(4):435-471. doi:10.1016/j.ecss.2008.09.003.

90. Bates, N. R.; Amat, A.; Andersson, A. J. Feedbacks and responses of coral calcification on the Bermuda reef system to seasonal changes in biological processes and ocean acidification. Biogeosciences. 2010, 7(8):2509-2530. doi:10.5194/bg-7-2509-2010.

91. Oh, T.; Sermsripong, J.; Hicks, B. W. Using scuba for in situ determination of chlorophyll distributions in corals by underwater near infrared fluorescence imaging. J. Mar. Sci. Eng. 2020, 8(1):53. doi:10.3390/JMSE8010053.

92. Treibitz, T.; Neal, B. P.; Kline, D. I.; et al. Wide Field-of-View Fluorescence Imaging of Coral Reefs. Sci. Rep. $2015,5$. doi:10.1038/srep07694.

93. Kenkel, C. D.; Traylor, M. R.; Wiedenmann, J.; Salih, A.; Matz, M. V. Fluorescence of coral larvae predicts their settlement response to crustose coralline algae and reflects stress. Proc. R. Soc. B Biol. Sci. 2011, 278(1718):2691-2697. doi:10.1098/rspb.2010.2344.

94. Roth, M. S.; Deheyn, D. D. Effects of cold stress and heat stress on coral fluorescence in reef-building corals. Sci. Rep. 2013, 3(1):1-8. doi:10.1038/srep01421.

95. Salih, A.; Larkum, A.; Cox, G.; Kühl, M.; Hoegh-Guldberg, O. Fluorescent pigments in corals are photoprotective. Nature. 2000, 408(6814):850-853. doi:10.1038/35048564.

96. Ramesh, C. H.; Koushik, S.; Shunmugaraj, T.; Ramana Murthy, M. V. A rapid in situ fluorescence census for coral reef monitoring. Reg. Stud. Mar. Sci. 2019, 28:100575. doi:10.1016/j.rsma.2019.100575.

97. Patterson, M. R.; Sebens, K. P.; Olson, R. R.; et al. In Situ Measurements of Flow Effects on Primary Production and Dark Respiration in Reef Corals. Vol 36.,; 1991.

98. Schreiber, U.; Schliwa, U.; Bilger, W. Continuous recording of photochemical and non-photochemical chlorophyll fluorescence quenching with a new type of modulation fluorometer. Photosynth. Res. 1986, 10(1-2):51-62. doi:10.1007/BF00024185.

99. Beer, S.; Ilan, M.; Eshel, A.; Weil, A.; Brickner, I. Use of pulse amplitude modulated (PAM) fluorometry for in situ measurements of photosynthesis in two Red Sea faviid corals. Mar. Biol. 1998, 131(4):607-612. doi:10.1007/s002270050352.

100. Ralph, P.; Gademann, R.; Larkum, A.; Schreiber, U. In situ underwater measurements of photosynthetic activity of coral zooxanthellae and other reef-dwelling dinoflagellate endosymbionts. Mar. Ecol. Prog. Ser. 1999, 180:139-147. doi:10.3354/meps180139.

101. Winters, G.; Loya, Y.; Röttgers, R.; Beer, S. Photoinhibition in shallow-water colonies of the coral Stylophora pistillata as measured in situ. Limnol. Oceanogr. 2003, 48(4):1388-1393. doi:10.4319/lo.2003.48.4.1388.

102. Piniak, G. A.; Storlazzi, C. D. Diurnal variability in turbidity and coral fluorescence on a fringing reef flat: Southern Molokai, Hawaii. Estuar. Coast. Shelf Sci. 2008, 77(1):56-64. doi:10.1016/j.ecss.2007.08.023.

103. Roder, C.; Wu, Z.; Richter, C.; Zhang, J. Coral reef degradation and metabolic performance of the scleractinian coral 
Porites lutea under anthropogenic impact along the NE coast of Hainan Island, South China Sea. Cont. Shelf Res. 2013, 57:123-131. doi:10.1016/j.csr.2012.11.017.

104. Banaszak, A. T.; Ayala-Schiaffino, N.; Rodriguez-Romàn, A.; Enriquez, S.; Iglesisas-Prieto, R. Response of Millepora Alcicornis (Milleporina: Milleporidae) to Two Bleaching Events at Puerto Morelos Reef, Mexican Caribbean PubMed. Rev. Biol. Trop. 2003, 51(4):57-66. Accessed June 29, 2020. https://pubmed.ncbi.nlm.nih.gov/15264554/.

105. Frade, P. R.; Englebert, N.; Faria, J.; Visser, P. M.; Bak, R. P. M. Distribution and photobiology of Symbiodinium types in different light environments for three colour morphs of the coral Madracis pharensis: Is there more to it than total irradiance? Coral Reefs. 2008, 27(4):913-925. doi:10.1007/s00338-008-0406-3.

106. Okamoto, M.; Nojima, S.; Furushima, Y.; Nojima, H. Evaluation of coral bleaching condition in situ using an underwater pulse amplitude modulated fluorometer. Fish. Sci. 2005, 71(4):847-854. doi:10.1111/j.14442906.2005.01036.x.

107. Suggett, D. J.; Kikuchi, R. K. P.; Oliveira, M. D. M.; Spanó, S.; Carvalho, R.; Smith, D. J. Photobiology of corals from Brazil's near-shore marginal reefs of Abrolhos. Mar. Biol. 2012, 159(7):1461-1473. doi:10.1007/s00227-012-1925-6.

108. Ralph, P. J.; Schreiber, U.; Gademann, R.; Kühl, M.; Larkum, A. W. D. Coral photobiology studied with a new imaging pulse amplitude modulated fluorometer. J. Phycol. 2005, 41(2):335-342. doi:10.1111/j.1529-8817.2005.04034.x.

109. Kromkamp, J. C.; Forster, R. M. The use of variable fluorescence measurements in aquatic ecosystems: Differences between multiple and single turnover measuring protocols and suggested terminology. Eur. J. Phycol. 2003, 38(2):103-112. doi:10.1080/0967026031000094094.

110. Suggett, D. J.; Oxborough, K.; Baker, N. R.; MacIntyre, H. L.; Kana, T. M.; Geider, R. J. Fast repetition rate and pulse amplitude modulation chlorophyll $a$ fluorescence measurements for assessment of photosynthetic electron transport in marine phytoplankton. Eur. J. Phycol. 2003, 38(4):371-384. doi:10.1080/09670260310001612655.

111. Gorbunov, M. Y.; Falkowski, P. G.; Kolber, Z. S. Measurement of photosynthetic parameters in benthic organisms in situ using a SCUBA-based fast repetition rate fluorometer. Limnol. Oceanogr. 2000, 45(1):242-245. doi:10.4319/1o.2000.45.1.0242.

112. Lombardi, M. R.; Lesser, M. P.; Gorbunov, M. Y. Fast repetition rate (FRR) fluorometry: Variability of chlorophyll a fluorescence yields in colonies of the corals, Montastraea faveolata (w.) and Diploria labyrinthiformes (h.) recovering from bleaching. J. Exp. Mar. Bio. Ecol. 2000, 252(1):75-84. doi:10.1016/S0022-0981(00)00238-0.

113. Lesser, M.; Gorbunov, M. Diurnal and bathymetric changes in chlorophyll fluorescence yields of reef corals measured in situ with a fast repetition rate fluorometer. Mar. Ecol. Prog. Ser. 2001, 212:69-77. doi:10.3354/meps212069.

114. Behrenfeld, M. J.; Kolber, Z. S. Widespread iron limitation of phytoplankton in the south pacific ocean. Science (80-. ). 1999, 283(5403):840-843. doi:10.1126/science.283.5403.840.

115. Falkowski, P. G.; Kolber, Z. Variations in chlorophyll fluorescence yields in phytoplankton in the world oceans. Aust. J. Plant Physiol. 1995, 22(2):341-355. doi:10.1071/PP9950341.

116. Lesser, M.; Gorbunov, M. Diurnal and bathymetric changes in chlorophyll fluorescence yields of reef corals measured in situ with a fast repetition rate fluorometer. Mar. Ecol. Prog. Ser. 2001, 212:69-77. doi:10.3354/meps212069.

117. Levy, O.; Achituv, Y.; Yacobi, Y. Z.; Dubinsky, Z.; Stambler, N. Diel "tuning" of coral metabolism: Physiological responses to light cues. J. Exp. Biol. 2006, 209(2):273-283. doi:10.1242/jeb.01983.

118. Levy, O.; Dubinsky, Z.; Achituv, Y. Photobehavior of stony corals: Responses to light spectra and intensity. J. Exp. Biol. 2003, 206(22):4041-4049. doi:10.1242/jeb.00622. 
803 119. Schneider, K.; Levy, O.; Dubinsky, Z.; Erez, J. In situ diel cycles of photosynthesis and calcification in hermatypic corals. Limnol. Oceanogr. 2009, 54(6):1995-2002. doi:10.4319/lo.2009.54.6.1995.

120. Patterson, M. R.; Sebens, K. P.; Olson, R. R. In situ measurements of flow effects on primary production and dark

121. Gattuso, J.-P.; Yellowlees, D.; Lesser, M. Depth-and light-dependent variation of carbon partitioning and utilization

122. Okazaki, R. R.; Swart, P. K.; Langdon, C. Stress-tolerant corals of Florida Bay are vulnerable to ocean acidification.

123. Nakamura, T.; Nakamori, T. A geochemical model for coral reef formation. Coral Reefs. 2007, 26(4):741-755. doi:10.1007/s00338-007-0262-6.

124. Wild, C.; Rasheed, M.; Jantzen, C.; et al. Benthic metabolism and degradation of natural particulate organic matter in carbonate and silicate reef sands of the northern Red Sea. Mar. Ecol. Prog. Ser. 2005, 298:69-78. doi:10.3354/meps298069.

125. Ferrier-Pagès, C.; Gevaert, F.; Reynaud, S.; et al. In situ assessment of the daily primary production of the temperate symbiotic coral Cladocora caespitosa. Limnol. Oceanogr. 2013, 58(4):1409-1418. doi:10.4319/lo.2013.58.4.1409.

126. Camp, E. F.; Krause, S. L.; Santos, L. M. F.; et al. The "Flexi-Chamber": A novel cost-effective in situ respirometry chamber for coral physiological measurements. PLoS One. 2015, 10(10):1-21. doi:10.1371/journal.pone.0138800.

127. Nakamura, T.; Nakamori, T. Estimation of photosynthesis and calcification rates at a fringing reef by accounting for diurnal variations and the zonation of coral reef communities on reef flat and slope: A case study for the Shiraho reef, Ishigaki Island, southwest Japan. Coral Reefs. 2009, 28(1):229-250. doi:10.1007/s00338-008-0454-8.

128. Pramneechote, P.; Sinutok, S.; Wongkamhaeng, K.; Chotikarn, P. An assessment of the net ecosystem metabolism and respiration of a tropical coral reef. Appl. Ecol. Environ. Res. 2020, 18(1). doi:10.15666/aeer/1801_18631881.

129. Wangpraseurt, D.; Polerecky, L.; Larkum, A. W. D.; et al. The in situ light microenvironment of corals. Limnol. Oceanogr. 2014, 59(3):917-926. doi:10.4319/lo.2014.59.3.0917.

130. Yates, K. K.; Halley, R. B. Measuring coral reef community metabolism using new benthic chamber technology. Coral

131. Gevaert, F.; Delebecq, G.; Menu, D.; Brutier, L. A fully automated system for measurements of photosynthetic

132. Shepard, A.; Dinsmore, D.; Miller, S.; Cooper, C.; Wicklund, R. Aquarius undersea laboratory: the next generation. Phaeophyceae). Limnol. Oceanogr. Methods. 2011, 9(9):361-379. doi:10.4319/lom.2011.9.361.

133. Carpenter, L. W.; Patterson, M. R.; Bromage, E. S. Water flow influences the spatiotemporal distribution of heat shock protein 70 within colonies of the scleractinian coral Montastrea annularis (Ellis and Solander, 1786) following heat stress: Implications for coral bleaching. J. Exp. Mar. Bio. Ecol. 2010, 387(1-2):52-59. doi:10.1016/j.jembe.2010.02.019. of the scleractinian coral Montastrea annularis (Ellis and Solander, 1786); implications for coral bleaching. J. Exp. Mar. Bio. Ecol. 2007, 351(1-2):10-26. doi:10.1016/j.jembe.2007.05.022. 
Pollut. Bull. 2017, 120(1-2):250-258. doi:10.1016/j.marpolbul.2017.05.025.

843 136. Haas, A. F.; Nelson, C. E.; Rohwer, F.; et al. Influence of coral and algal exudates on microbially mediated reef

140. Long, M. H.; Berg, P.; de Beer, D.; Zieman, J. C. In Situ Coral Reef Oxygen Metabolism: An Eddy Correlation Study. Davies, A., ed. PLoS One. 2013, 8(3):e58581. doi:10.1371/journal.pone.0058581.

141. Wangpraseurt, D.; Larkum, A. W. D.; Ralph, P. J.; Kühl, M. Light gradients and optical microniches in coral tissues. Front. Microbiol. 2012, 3(AUG). doi:10.3389/fmicb.2012.00316.

142. Takeshita, Y.; McGillis, W.; Briggs, E. M.; et al. Assessment of net community production and calcification of a coral reef using a boundary layer approach. J. Geophys. Res. Ocean. 2016, 121(8):5655-5671. doi:10.1002/2016JC011886.

143. McGillis, W. R.; Langdon, C.; Loose, B.; Yates, K. K.; Corredor, J. Productivity of a coral reef using boundary layer and enclosure methods. Geophys. Res. Lett. 2011, 38(3):n/a-n/a. doi:10.1029/2010GL046179.

144. Takeshita, Y.; Cyronak, T.; Martz, T. R.; Kindeberg, T.; Andersson, A. J. Coral Reef Carbonate Chemistry Variability at Different Functional Scales. Front. Mar. Sci. 2018, 5(MAY):175. doi:10.3389/fmars.2018.00175.

145. McMahon, A.; Santos, I. R.; Schulz, K. G.; Cyronak, T.; Maher, D. T. Determining coral reef calcification and primary production using automated alkalinity, $\mathrm{pH}$ and $\mathrm{pCO} 2$ measurements at high temporal resolution. Estuar. Coast. Shelf Sci. 2018, 209:80-88. doi:10.1016/j.ecss.2018.04.041.

146. Cyronak, T.; Andersson, A. J.; Langdon, C.; et al. Taking the metabolic pulse of the world's coral reefs. PLoS One. 2018, 13(1):1-17. doi:10.1371/journal.pone.0190872.

147. Shashar, N.; Cohen, Y.; Loya, Y. Extreme diel fluctuations of oxygen in diffusive boundary layers surrounding stony corals. Biol. Bull. 1993, 185(3):455-461. doi:10.2307/1542485.

148. Weber, M.; Faerber, P.; Meyer, V.; et al. In situ applications of a new diver-operated motorized microsensor profiler. Environ. Sci. Technol. 2007, 41(17):6210-6215. doi:10.1021/es070200b.

149. Wangpraseurt, D.; Weber, M.; Røy, H.; et al. In situ oxygen dynamics in coral-algal interactions. PLoS One. 2012, 7(2). doi:10.1371/journal.pone.0031192.

150. Brown, B. E.; Dunne, R. P.; Goodson, M. S.; Douglas, A. E. Experience shapes the susceptibility of a reef coral to bleaching. Coral Reefs. 2002, 21(2):119-126. doi:10.1007/s00338-002-0215-z.

151. Berg, P.; Røy, H.; Janssen, F.; et al. Oxygen uptake by aquatic sediments measured with a novel non-invasive eddycorrelation technique. Mar. Ecol. Prog. Ser. 2003, 261:75-83. doi:10.3354/meps261075.

879 152. Long, M. H.; Berg, P.; de Beer, D.; Zieman, J. C. In Situ Coral Reef Oxygen Metabolism: An Eddy Correlation Study. 
880 Davies, A., ed. PLoS One. 2013, 8(3):e58581. doi:10.1371/journal.pone.0058581.

881 153. Rovelli, L.; Attard, K. M.; Bryant, L. D.; et al. Benthic O<inf $>2</$ inf $>$ uptake of two cold-water coral communities estimated with the non-invasive eddy correlation technique. Mar. Ecol. Prog. Ser. 2015, 525:97-104. doi:10.3354/meps11211.

884 154. de Froe, E.; Rovelli, L.; Glud, R. N.; et al. Benthic Oxygen and Nitrogen Exchange on a Cold-Water Coral Reef in the North-East Atlantic Ocean. Front. Mar. Sci. 2019, 6:665. doi:10.3389/fmars.2019.00665.

155. Takeshita, Y.; McGillis, W.; Briggs, E. M.; et al. Assessment of net community production and calcification of a coral reef using a boundary layer approach. J. Geophys. Res. Ocean. 2016, 121(8):5655-5671. doi:10.1002/2016JC011886.

156. Mass, T.; Brickner, I.; Hendy, E.; Genin, A. Enduring physiological and reproductive benefits of enhanced flow for a stony coral. Limnol. Oceanogr. 2011, 56(6):2176-2188. doi:10.4319/lo.2011.56.6.2176.

890 157. Doo, S. S.; Edmunds, P. J.; Carpenter, R. C. Ocean acidification effects on in situ coral reef metabolism. Sci. Rep. 2019, 9(1):1-8. doi:10.1038/s41598-019-48407-7.

158. Kline, D. I.; Teneva, L.; Schneider, K.; et al. A short-term in situ CO 2 enrichment experiment on Heron Island (GBR). Sci. Rep. 2012, 2(1):1-9. doi:10.1038/srep00413.

159. Albright, R.; Takeshita, Y.; Koweek, D. A.; et al. Carbon dioxide addition to coral reef waters suppresses net community calcification. Nature. 2018, 555(7697):516-519. doi:10.1038/nature25968.

160. Albright, R.; Caldeira, L.; Hosfelt, J.; et al. Reversal of ocean acidification enhances net coral reef calcification. Nature. 2016, 531(7594):362-365. doi:10.1038/nature17155.

161. Albright, R.; Takeshita, Y.; Koweek, D. A.; et al. Carbon dioxide addition to coral reef waters suppresses net community calcification. Nature. 2018, 555(7697):516-519. doi:10.1038/nature25968.

162. Shaw, E. C.; Phinn, S. R.; Tilbrook, B.; Steven, A. Natural in situ relationships suggest coral reef calcium carbonate production will decline with ocean acidification. Limnol. Oceanogr. 2015, 60(3):777-788. doi:10.1002/lno.10048.

902 163. Anthony, K. R. N.; A. Kleypas, J.; Gattuso, J. P. Coral reefs modify their seawater carbon chemistry - implications for 